\title{
Who ARE the ReleVANT StaKeHOlders to THE LOCAL GOVERNMENT CONTEXT? EMPIRICAL EVIDENCES ON ENVIRONMENTAL INFLUENCES IN THE DECISION-MAKING PROCESS OF ENGLISH LOCAL AUTHORITIES
}

\author{
Ricardo Corrêa Gomes* \\ E-mail address: rgomes@ufv.br \\ Universidade Federal de Viçosa \\ Viçosa, MG, Brazil
}

\begin{abstract}
This article presents empirical evidence of stakeholding in the local government context. It is the result of a survey carried out with English Local Authorities in 2001. It outlines the arena in which local government make decisions by pinpointing the relevant stakeholders in the process as well as the amount of power they are perceived to represent by chief executives. The investigation has its theoretical basis in resource dependence and institutional theories, which are commonly used for explaining an organization's behaviour and performance as influenced by its environment. As an empirical contribution, the article proposes a stakeholder map for any kind of local government organizations that will help in identifying strategies for managing stakeholders.
\end{abstract}

Key words: public management; local government; strategic management; stakeholder analysis.

Received 16 December 2003; received in revised form 10 March 2004.

Copyright (C) 2004 Brazilian Administration Review. All rights reserved, including rights for translation. Parts of this work may be quoted without prior knowledge on the condition that the source is identified.

\footnotetext{
* Corresponding author: Ricardo Corrêa Gomes

Rua Antônio Torres, 79, apto. 302, Bairro Ramos, Viçosa, MG, 36570-000, Brazil.

Tel.: +553138924687.
} 


\section{INTRODUCTION}

Despite being in management literature (STONEY; WINSTANLEY, 2001) since Richard E. Freeman published his landmark book "Strategic Management: A Stakeholder Approach" in 1984, stakeholding has yet to be fully explored in the Public Management field, with little empirical evidence in local government studies. The sporadic examples of stakeholding in Public Management are to be found in studies involving public services such as hospitals (FOTTLER et al., 1989), health care (BLAIR; BUESSELER, 1998; KUMAR; SUBRAMANIAN, 1998; MILLER; WILSON, 1998;), and education (ENZ et al., 1993).

As a non-finished theory, stakeholder theory is often related to other theories such as Resource Dependence, Institutionalism, Agency Theory, Resource-Based Theory and even Transaction Cost Analysis. The decision on the adequate theory relies upon the investigation's aims. In this investigation, resource dependence and institutional theories are used because the main aim is to find out how a specific type of organization (local government) behaves and performs when influenced by external and internal stakeholders.

Donaldson and Preston (1995) have suggested that stakeholder theory has been developed by employing three theoretical bases: normative, descriptive and instrumental. Normative studies are concerned with the nature of the relationships formed between stakeholders and organizations. In some cases, it is a matter of how ethical these relationships are. Descriptive/empirical studies aim "to describe, and sometimes to explain, specific corporate characteristics and behaviors basis" (DONALDSON; PRESTON, 1995, p. 70). Instrumental studies focus on tracking down "connections, if any, between the practice of stakeholder management and the achievement of various corporate performance goals" (DONALDSON; PRESTON, 1995, p. 67).

This paper aims to contribute to the discussion on the importance of the stakeholder theory for local government performance by delivering empirical/descriptive evidence on stakeholder identification and salience. To do so, it presents the results of a survey carried out with chief executives of English Local Authorities. As its main product, the paper proposes a stakeholder's list with the relevant actors and a stakeholder map in which power and influence are balanced in order to depict the people, groups or organizations that are likely to represent either a threat, or an opportunity to the decision-making process of such organizations.

\section{THEORETICAL FRAMEWORK AND HYPOTHESES}

Freeman (1984) in one of the most frequently quoted studies in stakeholder theory, defines a stakeholder as "any group or individual who can affect or is affected by the achievement of the organization's objectives". Bryson (1995) expanded the definition in the following way: "A stakeholder is defined as any person, group, or organization that can place a claim on an organization's attention, resources, or output or is affected by that output".

This investigation employs the stakeholder concept based on the assumption that organizations are neither self-sufficient nor isolated from its external environment (PFEFFER; SALANCIK, 1978). As a main tenet of the Open System Theory (KATZ; KAHN, 1978), organizations engage relationships with their environments in order to get the critical resources for their productive processes (PFEFFER; SALANCIK, 1978), and the required legitimacy for their activities (SELZNICK, 1966).

The following quotation, extracted from the Open System Theory, illustrates the extent to which organizations are shaped by external forces: "The behavior of an organization is contingent upon the social field of forces in which it occurs and must be understood in terms of the organization's interaction with that environmental field" (KATZ; KAHN, 1978, p. 3). 
Scott (1998) argues that environments could be classified as technical and institutional. The technical environment relates to the production of goods and services and the institutional relates to the set of norms, values, rituals and patterns of behavior. Thus, an organization inhabits both technical and institutional-based environments and, in so doing, it is exposed to the influences stemming from them. Technical influences affect the way organizations behave in their productive processes, and institutional influences affect the organization's "conformity with social rules and rituals" (ORRUं et al., 1991, p. 361). Furthermore, organizations are pretty much shaped by environmental pressures (ORRÙ et al., 1991, p. 361).

Connected with the open system's view, the resource dependence perspective (PFEFFER; SALANCIK, 1978, p. 5) is based on the assumption that "the key to organizational survival is the ability to acquire and maintain resources" which are owned by the external agents who are therefore able to exert influence over the organization. As organizations are dependent upon resources from environments, the resource dependence perspective anticipates that they need to adjust themselves to environmental standards in order to survive. Other authors such as (MWANKWO; RICHARDSON, 1996) agree with that assumption, suggesting that organizations survive to the extent that they are able to cope with demands and expectations from the external environment.

Another perspective well connected with the open system's view is the institutional theory, which explains an organization's behavior as conforming to norms and patterns of behavior created by institutions. In this vein, Meyer and Rowan (1991) state: "Organizations are driven to incorporate new practices and procedures defined by prevailing rationalized concepts of organizational work and institutionalized in society".

In other words, the institutional environment which an organization inhabits is regulated by norms, values and patterns of behavior to which the organizations need to conform in order to be accepted. Hannan and Freeman (1977), in their classical ecological perspective, argued that organizations conform in order to avoid being excluded from the environment. Dimaggio and Powell (1991) as well as Meyer and Rowan, 1991 focus on the problems that stem from the organization reproducing institutionalized behaviors, which they label as isomorphism. According to them, organizations start to look alike, losing identity and capacity for innovation. Orrù et al. (1991) warn that isomorphism is a phenomenon common to both technical and institutional environments. According to them (ORRUं et al., 1991), the technical environment forces organizations into competitive isomorphism and the institutional environment into institutional isomorphism. The following quotation summarizes the above ideas:

According to both institutional and resource dependence perspectives, organizational choice is limited by a variety of external pressures, environments are collective and interconnected, and organizations must be responsive to external demands and expectations in order to survive (OLIVER, 1991, p. 146).

Agreeing with the argument above, Greening and Gray (1994) suggest that "both institutional and resource dependence theories offer explanations for why firms adopt certain structural modifications". The combination of these two perspectives should explain the patterns of relationships formed between a local government organization and its stakeholders.

Applying Freeman's perspective, this investigation assumes that stakeholders are the environmental agents able to exert technical and institutional influences upon organizations. Based on this argument, the stakeholder theory can be seen as the approach that combines resource dependence and institutional perspectives in order to understand environmental influences.

As any organization, local governments need resources in order to be able to carry out their responsibilities and they also need legitimacy for their activities in order to be accepted by society. In the specific case of local government organizations, they have their effectiveness judged upon recognition. Nobody will show up to vote unless they are convinced that the councilors deserve it. Figure 1 indicates the arena in which local government organizations embrace relationships with their 
stakeholders (environmental influences). It shows a two-way relationship in which stakeholders contribute with some sort of influence and they expect some sort of return.

Figure 1: The Conceptual Links Between an Organization and its Environment

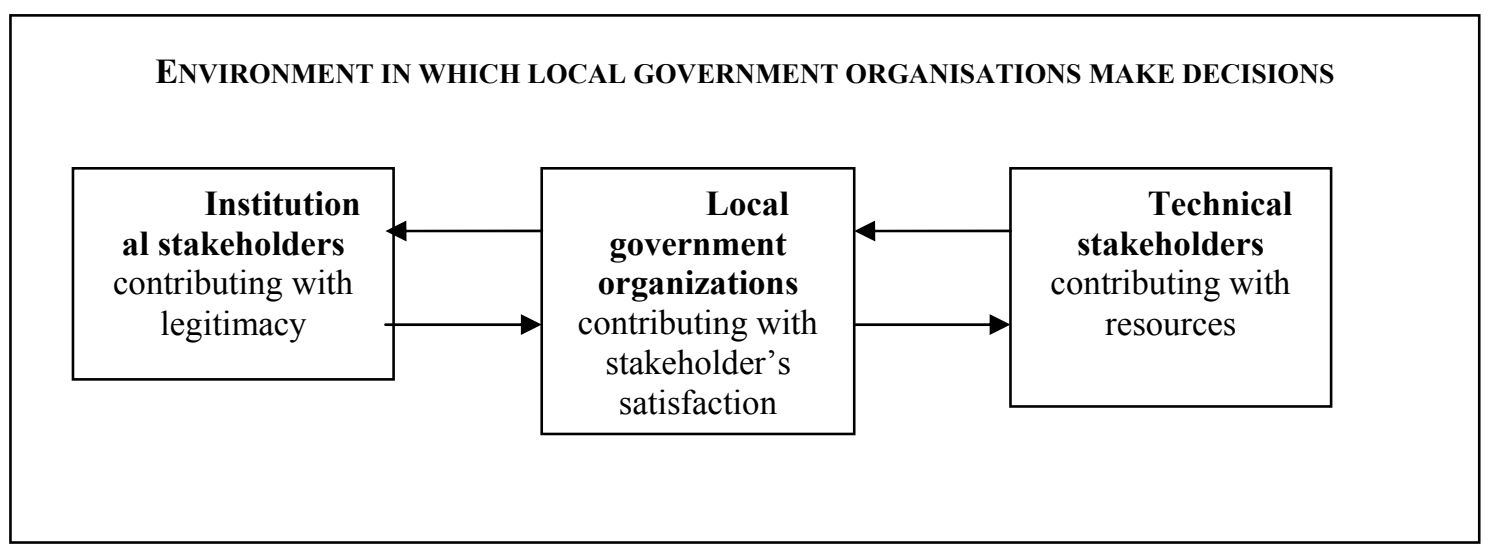

Source: adapted from Oliver (1991) and Greening \& Gray (1994).

As part of the stakeholder management process, Mitchell et al. (1997) argue that organizations have to identify and assess their stakeholders as well as their salience (measurement of power and influence) in order to devise proper strategies for dealing with them. Bryson (1995) suggested a sixstep process for scanning organizational environment in search of stakeholder identification. The steps are presented below:

1. To identify organization's main stakeholders;

2. To specify the criteria stakeholders use to assess the organization's performance;

3. To identify whether the organization is attending stakeholders' demands;

4. To identify how stakeholder's influence comes about;

5. To identify what the organization needs from these stakeholders;

6. To identify how important each stakeholder can be for the organization.

\section{Stakeholder Identification Process}

For accomplishing the first step, Freeman (1984) suggested a two-dimension grid based on concepts of power and interest (stake). Mitchell et al. (1997) contributed to stakeholder's identification by proposing a model in which attributes of power, legitimacy, and urgency are combined. Winstanley et al. (1995) proposed a framework for assessing a stakeholder's salience in public service organizations based on two dimensions of power: criteria power and operational power. The former is a dimension for assessing stakeholder's power to influence issues about planning such as the definition of objectives and the definition of performance criteria. The latter is a dimension for assessing the stakeholder's power to influence the service delivery process. This investigation employs this model whose attributes of power are dealt with as follows.

According to Mintzberg (1983), power is the capacity for making someone do what he or she otherwise would not do. He suggests five bases in which power is likely to occur: 
. Control of resources;

. Control of a technical skill;

. Control of a body of knowledge;

. Power from legal prerogatives; and

. Access to those who can rely on the previous sources of power.

Etzione (quoted by MITCHELL et al., 1997) suggest that power is likely to result from three contextual dimensions: normative power, coercive power, and utilitarian power. Normative power results from laws and requirements over which the organization has no control. Coercive power stems from physical means and utilitarian power results from dependence (PFEFFER; SALANCIK, 1978) because the organization sometimes has to go against its own will in order to gain resources.

Hardy (1996 quoting LUKES, 1974) suggests that power stems from resources, processes and meaning. The first dimension of power is derived from the ownership of resources. People who own some type of resources are more likely to coerce others to behave according to their will. For example, "information, expertise, political access, credibility, stature and prestige, access to higher echelon members, the control of money, rewards and sanctions" (HARDY, 1996, p. S7). Pfeffer and Salancik (1978) employ this concept to explain dependency.

Power also stems from the decision-making process, and people who have domination over such processes are entitled to coerce others by applying or not "procedures and political routines" (HARDY, 1996, p. S7). The third dimension of power is meaning, which is related to the power to prevent "conflict from emerging in the first place" (HARDY, 1996, p. S8). That is, some people have control over the status quo and, in doing so, can suppress others of their cognition. These two bases of power can also be related to the environmental influences upon organizations to the extent that political and professional issues arise from its pressuring the organization to comply with their requirements.

\section{Issues in Stakeholder's Salience}

Aiming to assess stakeholder salience, Savage et al. (1991) propose a matrix that combines the stakeholder's potential to threaten the organization combined with the stakeholder's potential to cooperate with the organization. The combination of these two dimensions produces four types of stakeholders: Supportive Stakeholders (low potential to threaten but high potential to co-operate), Marginal Stakeholders (low potential to threaten and low potential to co-operate), Nonsupportive Stakeholders (high potential to threaten but low potential to co-operate), and Mixed Blessing Stakeholders (high potential to threaten as well as to co-operate) (SAVAGE, 1991, p. 65).

From the literature review, it can be seen that organizations inhabit technical and institutional environments. In both instances, the organization is exposed to influences that can alter its form and behavior. The stakeholder theory may offer alternatives to diminish the complexity of such environmental confusion as it makes it possible to pinpoint individual environmental influences. For this reason, the organization needs to identify the stakeholders as well as the opportunity/threat they represent, in order to devise effective strategies for dealing with them.

\section{RESEARCH METHODS}

\section{Research Context}

English local authorities can be classified as urban and rural, despite the controversy that this classification would arouse. In order to avoid this controversy, the study follows the Countryside Agency's classification, which indicates the authorities regarded as rural. According the Agency, these 
regions are characterized by low population density and primary industry activities. For methodological reasons, the study regards the other areas as non-rural, encompassing urban and suburban areas. The figure below indicates the rural (the gray areas in the map) and non-rural areas.

\section{Figure 2: England's Map for Differing Rural and Non-Rural Areas}
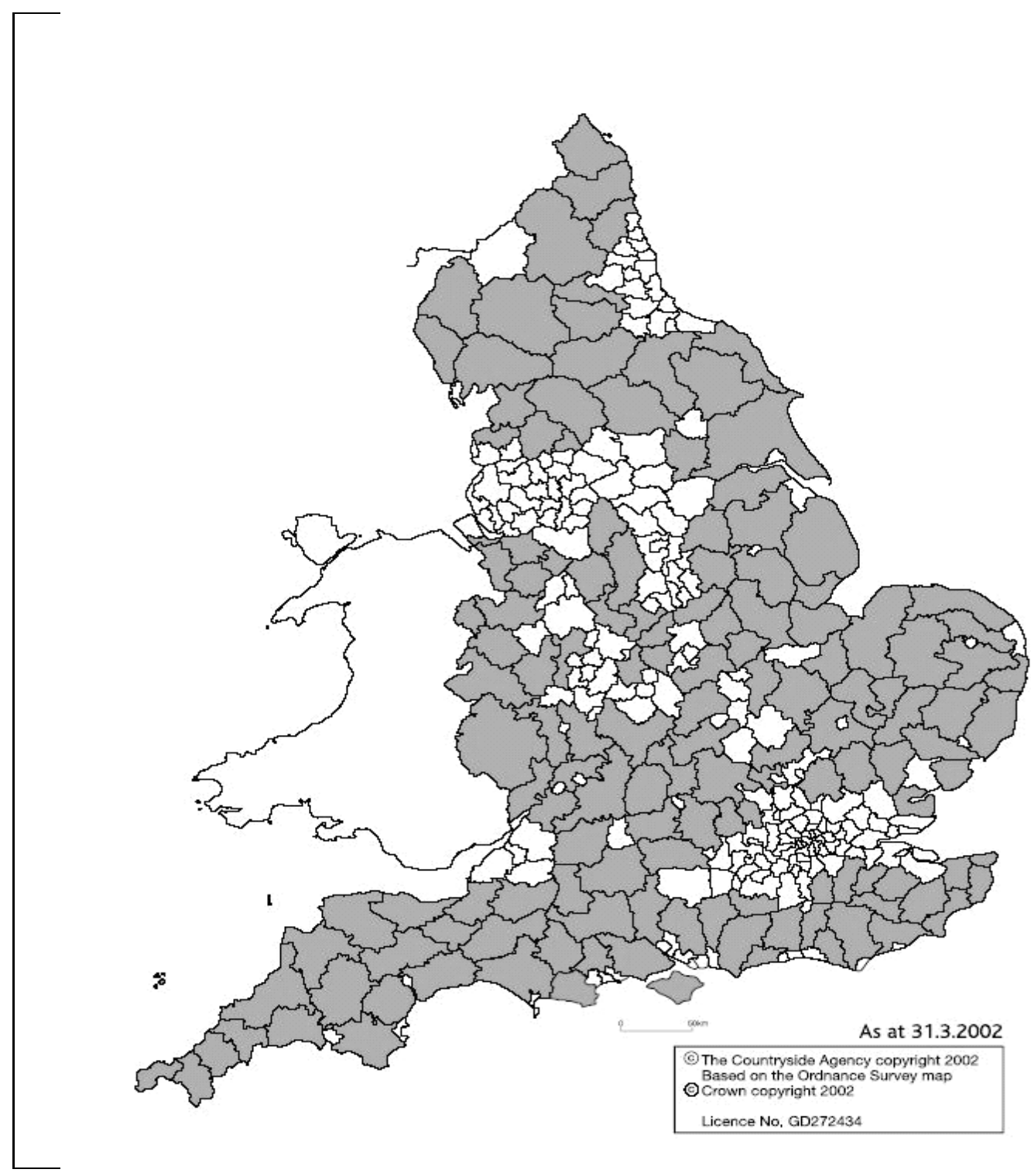

Source: the Countryside Agency (Reproduced with permission) available from www.countryside.gov.uk

According to the Municipal Year Book (2000) there are five different types of local government structures within England and they are County Councils, District Councils, Metropolitan District Councils, London Borough Councils and Unitary Councils. County Councils are composed of District Councils with which they share the delivery of some specific services. For example, District Councils are responsible for collecting waste while County Councils for its disposal.

The definitive urban areas are the Metropolitan District Councils and the London Borough Councils (which comprise the Great London metropolitan area). These authorities are autonomous and responsible for the delivery of all the public services in their territories. The current English political structure at the time this investigation was carried out is in Table 2. 
English local authorities are led by councilors who are periodically elected by democratic elections (MUNICIPAL YEARBOOK, 2000). The dominant political leadership that achieves the majority of the votes has the right to appoint the mayor (Mayor or Lord Mayor). A Chief Executive is a professional appointed to manage the administrative structure. Within the managerial structure, there are departments responsible for delivering public services (MUNICIPAL YEAR BOOK, 2000).

Table 1: The Composition of the English Local Authorities System

\begin{tabular}{|l|l|}
\hline Authorities & Quantity \\
\hline County Councils & 34 \\
\hline London Borough Councils & 31 \\
\hline Corporation of London & 1 \\
\hline Metropolitan Councils & 36 \\
\hline District Councils & 237 \\
\hline Unitary Councils & 46 \\
\hline Total & 385 \\
\hline
\end{tabular}

Source: Municipal Yearbook, 2000.

In England there are several political parties. They are the Labour Party (now leading central government), the Conservative Party (the main opposition party), the Liberal Democrat Party, the Independent Party and others with low representation. The Local Government Association Agency, an organization whose aim is to support and represent local authorities, publishes the list of local authorities and their respective controllers. Table 2 illustrates the political control of English local authorities at the time the investigation was carried out.

Table 2: English Political Parties and their Representation on Controlling Councils

\begin{tabular}{|l|l|}
\hline Political Parties & Control over Local Authorities \\
\hline Labour & $33 \%$ \\
\hline Conservative & $24 \%$ \\
\hline No-overall control & $33 \%$ \\
\hline Liberal Democratic & $7 \%$ \\
\hline Independent & $3 \%$ \\
\hline Total & $100 \%$ \\
\hline
\end{tabular}

Source: adapted from the Local Government Association world web wide available from http://www.lga.gov.uk.

\section{Data Collection}

The investigation was undertaken by surveying Chief Executives of English Local Authorities in the period of February to June 2001. The investigation used questionnaires, which were sent to 350 local authorities. The questionnaire was addressed to chief executives due to their position in the administrative structure and also because these people are professionals who remain in authority regardless of the electoral changes in the council. The questionnaire aimed to identify who is likely to 
be a stakeholder for the whole local authority in the chief executive's view as well as how much influence these stakeholders are likely to represent in the decision-making process arena.

The questionnaire was structured upon two questions. The first asked the respondent to name who they believe is a stakeholder able to exert influence in the decision-making process. It was an open question aiming to raise as many names as possible. The second question asked the respondents to rate stakeholder's salience according to seven criteria and based on a one-dimensioned and Lickert scale of five levels (from no influence to strong influence). The criteria were based on concepts of power that are outlined in the literature section and presented as follows.

1. Power to influence decisions concerning objectives;

2. Power to influence decisions about how services are to be delivered;

3. Power to influence criteria about performance appraisal;

4. Power as a result of being a stakeholder whose satisfaction is an aim for the Authority;

5. Power to control critical assets (money and supplies);

6. Power to control technical skills;

7. Power to influence the service delivery process.

\section{Research Variables}

The survey's main aims were to gather data to develop two indexes, namely the stakeholder nomination index (SNI) and the stakeholder salience index (SSI). The SNI was developed to identify the most 'popular' stakeholders in chief executives' view. This index is calculated by comparing the number of nominations a stakeholder received with the total of valid responses. The result is a value situated on a scale of 0 to 1 , which is represented by a ratio type variable. The SSI was developed to identify the most influential stakeholders and is calculated by averaging the salience scores achieved by each stakeholder in each criterion, i.e. each stakeholder is associated with a value from the Lickert scale from 0 and 5 and this is his/her SSI in the criterion.

\section{FINDINGS}

After only one wave of posted questionnaires, whose delivery was confirmed by telephone calls, fax machine contacts and electronic mails, 71 questionnaires were returned. The table below details the response rate. The total of useful questionnaires represented $20 \%$ of the population, which according to Rahman (2001) is a fully acceptable result for mail questionnaires. Furthermore, the response may be regarded as a good sample of the universe considering the situation when the investigation was being carried out which was marked by the foot and mouth crisis, as well as the approach of the electoral period.

Table 3: Response Rate Explained

\begin{tabular}{|l|l|l|l|l|}
\hline \multicolumn{2}{|l|}{ Population } & $\%$ & Returned Questionnaires & Response Rate \\
\hline Rural & 141 & $40 \%$ & 26 & $37 \%$ \\
\hline Non-Rural & 209 & $60 \%$ & 45 & $63 \%$ \\
\hline Conservative & 84 & $24 \%$ & 14 & $20 \%$ \\
\hline Labour & 118 & $34 \%$ & 23 & $32 \%$ \\
\hline
\end{tabular}




\begin{tabular}{|l|l|l|l|l|}
\hline Liberal Democrat & 25 & $7 \%$ & 3 & $4 \%$ \\
\hline No-overall control & 113 & $32 \%$ & 29 & $41 \%$ \\
\hline Others & 10 & $3 \%$ & 2 & $3 \%$ \\
\hline District Councils & 237 & $68 \%$ & 41 & $58 \%$ \\
\hline London Boroughs & 31 & $9 \%$ & 9 & $13 \%$ \\
\hline $\begin{array}{l}\text { Metropolitan } \\
\text { Districts }\end{array}$ & 36 & $10 \%$ & 10 & $14 \%$ \\
\hline Unitary Councils & 46 & $13 \%$ & 11 & $15 \%$ \\
\hline Total & $\mathbf{3 5 0}$ & $\mathbf{1 0 0} \%$ & $\mathbf{7 1}$ & $14 \%$ \\
\hline Unanswered questionnaires & 10 & $10 \%$ \\
\hline Questionnaires returned by the Post Office & 35 & $20 \%$ \\
\hline Useful Questionnaires & 61 & \\
\hline
\end{tabular}

Source: data Analysis.

\section{Question 1: Who are English Local Government's Stakeholders?}

According to chief executives' responses, a large number of stakeholders are able to influence decision-making. Due to the diversity of stakeholders nominated, a similarity analysis was needed, which resulted in a list of twenty-two different stakeholders, groups of stakeholders and even categories of stakeholders.

Table 4: SNI - Results from the Opinion Survey

\begin{tabular}{|c|c|c|c|c|c|c|}
\hline \multirow[t]{2}{*}{ Stakeholders } & \multicolumn{2}{|c|}{$\begin{array}{l}\text { Geographical } \\
\text { Differences }\end{array}$} & \multicolumn{3}{|c|}{$\begin{array}{ll}\text { Political } & \text { Leadership } \\
\text { Differences }\end{array}$} & \multirow{2}{*}{$\begin{array}{l}\text { Overall } \\
\text { Nomination }\end{array}$} \\
\hline & Non-Rural & Rural & Lab & Con & NOC & \\
\hline Audit Commission & $29 \%$ & $29 \%$ & $24 \%$ & $22 \%$ & $29 \%$ & $33 \%$ \\
\hline Central Government & $100 \%$ & $92 \%$ & $100 \%$ & $89 \%$ & $96 \%$ & $97 \%$ \\
\hline Citizens & $94 \%$ & $92 \%$ & $100 \%$ & $100 \%$ & $92 \%$ & $93 \%$ \\
\hline Contractors & $35 \%$ & $29 \%$ & $38 \%$ & $33 \%$ & $38 \%$ & $36 \%$ \\
\hline Councilors & $65 \%$ & $67 \%$ & $62 \%$ & $67 \%$ & $83 \%$ & $67 \%$ \\
\hline Employees & $68 \%$ & $71 \%$ & $81 \%$ & $56 \%$ & $75 \%$ & $70 \%$ \\
\hline Fire Authorities & $44 \%$ & $29 \%$ & $57 \%$ & $22 \%$ & $46 \%$ & $41 \%$ \\
\hline Further Education & $35 \%$ & $21 \%$ & $52 \%$ & $22 \%$ & $21 \%$ & $33 \%$ \\
\hline Health Authorities & $82 \%$ & $63 \%$ & $81 \%$ & $67 \%$ & $75 \%$ & $75 \%$ \\
\hline Local Business & $85 \%$ & $92 \%$ & $81 \%$ & $100 \%$ & $83 \%$ & $89 \%$ \\
\hline Local Media & $53 \%$ & $54 \%$ & $52 \%$ & $56 \%$ & $58 \%$ & $56 \%$ \\
\hline Lower Tie Authorities & $32 \%$ & $38 \%$ & $29 \%$ & $67 \%$ & $38 \%$ & $34 \%$ \\
\hline Management Team & $32 \%$ & $29 \%$ & $29 \%$ & $33 \%$ & $38 \%$ & $34 \%$ \\
\hline Other Local Authorities & $32 \%$ & $21 \%$ & $38 \%$ & $11 \%$ & $29 \%$ & $31 \%$ \\
\hline Partner Agencies & $32 \%$ & $38 \%$ & $24 \%$ & $33 \%$ & $38 \%$ & $38 \%$ \\
\hline Police Authorities & $85 \%$ & $63 \%$ & $81 \%$ & $67 \%$ & $75 \%$ & $77 \%$ \\
\hline Political Parties in & $41 \%$ & $33 \%$ & $43 \%$ & $44 \%$ & $38 \%$ & $41 \%$ \\
\hline
\end{tabular}




\begin{tabular}{|l|l|l|l|l|l|l|}
\hline General & & & & & & \\
\hline Pressure Groups & $62 \%$ & $50 \%$ & $67 \%$ & $67 \%$ & $46 \%$ & $59 \%$ \\
\hline Service Users & $56 \%$ & $46 \%$ & $52 \%$ & $67 \%$ & $63 \%$ & $54 \%$ \\
\hline Trade Unions & $24 \%$ & $25 \%$ & $24 \%$ & $22 \%$ & $25 \%$ & $28 \%$ \\
\hline Upper Tie Authorities & $50 \%$ & $54 \%$ & $62 \%$ & $44 \%$ & $63 \%$ & $51 \%$ \\
\hline Voluntary Sector & $77 \%$ & $63 \%$ & $71 \%$ & $78 \%$ & $63 \%$ & $72 \%$ \\
\hline
\end{tabular}

Source: Data Analysis.

Table 4 demonstrates the final stakeholder's list. The table is structured in order to demonstrate the extent to which stakeholder identification is associated with the geographical and political contexts. In the table, the last column represents the overall SNI, i.e., stakeholder nomination regardless of the type of the authority, the geographical differences or the political context. The other columns indicate SNI as classified by geographical and political differences. In this analysis, SNI results have a confidence level of 0.01 .

According to the findings, central government was the highest nominated stakeholder according to the opinion of $97 \%$ of the respondents. And it was nominated by $100 \%$ of non-rural authorities, $92 \%$ of rural authorities, $100 \%$ of Labour authorities, $89 \%$ of Conservatives and $96 \%$ of no-overall control authorities.

The other highest nominated stakeholder were citizens who received a nomination rate of $93 \%$ of the respondents overall. The evidence indicated that citizens were indicated as a stakeholder by $94 \%$ of non-rural authorities, $92 \%$ of rural authorities, $100 \%$ of Labour authorities, $100 \%$ of Conservative authorities and $92 \%$ of no-overall control authorities.

The local businesses are another highly nominated stakeholder and they overall SNI was $89 \%$. Particularizing the preferences, $85 \%$ of non-rural authorities, $92 \%$ of rural authorities, $81 \%$ of Labour authorities, $100 \%$ of Conservative authorities, and $83 \%$ of no-overall control authorities have nominated the local businesses as a stakeholder.

Table 5: Pearson's Moment Correlation

\begin{tabular}{|ll|r|r|r|r|r|}
\hline \multicolumn{7}{|c|}{ Pearson's Moment Correlations } \\
\hline & & Non-Rural & \multicolumn{1}{c|}{ RURAL } & LABOUR & Conser. & Non-Overall \\
\hline Non-Rural & Pearson Correlation & 1.000 & $.931^{* *}$ & $.956^{* *}$ & $.868^{* *}$ & $.931^{* *}$ \\
& Sig. (2-tailed) &. & .000 & .000 & .000 & .000 \\
& $\mathrm{~N}$ & 22 & 22 & 22 & 22 & 22 \\
\hline RURAL & Pearson Correlation & $.931^{* *}$ & 1.000 & $.871^{* *}$ & $.911^{* *}$ & $.955^{* *}$ \\
& Sig. (2-tailed) & .000 &. & .000 & .000 & .000 \\
& $\mathrm{~N}$ & 22 & 22 & 22 & 22 & 22 \\
\hline LABOUR & Pearson Correlation & $.956^{* *}$ & $.871^{* *}$ & 1.000 & $.766^{* *}$ & $.879^{* *}$ \\
& Sig. (2-tailed) & .000 & .000 &. & .000 & .000 \\
& $\mathrm{~N}$ & 22 & 22 & 22 & 22 & 22 \\
\hline Conser. & Pearson Correlation & $.868^{* *}$ & $.911^{* *}$ & $.766^{* *}$ & 1.000 & $.848^{* *}$ \\
& Sig. (2-tailed) & .000 & .000 & .000 &. & .000 \\
& $\mathrm{~N}$ & 22 & 22 & 22 & 22 & 22 \\
\hline Non-Overall & Pearson Correlation & $.931^{* *}$ & $.955^{* *}$ & $.879^{* *}$ & $.848^{* *}$ & 1.000 \\
& Sig. (2-tailed) & .000 & .000 & .000 & .000 &. \\
& $\mathrm{~N}$ & 22 & 22 & 22 & 22 & 22 \\
\hline
\end{tabular}

${ }^{* *}$. Correlation is significant at the 0.01 level (2-tailed).

On the other hand, Trade Unions were the lowest nominated stakeholder with an SNI of $28 \%$. Particularizing the preferences, $24 \%$ of non-rural authorities, $25 \%$ of rural authorities, $24 \%$ of Labour authorities, $22 \%$ of Conservative authorities, and $25 \%$ of no-overall control authorities have nominated Trade Unions as a stakeholder. 
Despite the numerical differences perceived among stakeholder's nomination, there is strong statistical association when comparing the different categories in pairs. For assessing statistical association, Person's moment correlation was used to calculate the statistical association between variables. Bryman (2001) suggested that type of statistical calculation as the most appropriate for interval/ratio variables. Table 6 presents the results for this calculation.

Using the SPSS, the smaller result is found in the analysis of Labour and Conservative authorities preferences whose result is $r=0.766$. According to Miller and Salkind (2002) it represents a strong useful relationship. All the other results are higher than 0.8 and they are considered as a strong correlation. This evidence indicates that geographical and political context are not a determining issue in stakeholder nomination, at least in the chief executives' view.

\section{Question 2: How Influential are Stakeholders Perceived Tobe by Chief Executives?}

The questionnaire's second question asked respondents to rate stakeholder's influences according to seven criteria of assessment. The results of the statistical analysis are presented below, split into two groups. The first comprises criteria one to four, and they relate to the strategy formulation process. The second comprises the criteria five to seven, and they relate to the service delivery process. The results comprise the statistical mean of the rates each stakeholder received by the criterion and the standard error of the mean.

\section{Criterion 1: The Definition of Objectives}

In criterion 1, the respondents were asked to indicate how much influence each stakeholder represents in decisions about objectives. According to the respondents, the councilors are regarded as the strongest influential stakeholder with an SSI of 4.87 with a confidence level of 0.05 , i.e. councilor's SSI is likely to vary from 4.82 to 4.92 . The management team is also regarded as a strong influential stakeholder $(4.50 ; 0.15)$.

Table 6: Stakeholders' Power to Influence Strategy Formulation

\begin{tabular}{|l|l|l|l|l|l|l|l|l|}
\hline \multirow{2}{*}{ Stakeholders } & \multicolumn{2}{|l|}{ Criterion 1 } & \multicolumn{2}{l|}{ Criterion 2 } & \multicolumn{2}{l|}{ Criterion 3 } & \multicolumn{2}{l|}{ Criterion 4 } \\
\cline { 2 - 10 } & $\begin{array}{l}\text { Mea } \\
\text { n }\end{array}$ & $\mathbf{S E}$ & $\begin{array}{l}\text { Mea } \\
\text { n }\end{array}$ & SE & $\begin{array}{l}\text { Mea } \\
\text { n }\end{array}$ & SE & $\begin{array}{l}\text { Mea } \\
\text { n }\end{array}$ & SE \\
\hline Audit Commission & 2.63 & 0.27 & 3.13 & 0.30 & 4.71 & 0.13 & 3.36 & 0.33 \\
\hline Central Government & 3.91 & 0.14 & 3.88 & 0.14 & 4.62 & 0.10 & 3.62 & 0.16 \\
\hline Citizens & 3.58 & 0.14 & 3.37 & 0.13 & 2.42 & 0.14 & 4.27 & 0.13 \\
\hline Contractors & 2.17 & 0.34 & 2.11 & 0.28 & 1.95 & 0.26 & 2.22 & 0.30 \\
\hline Councilors & 4.87 & 0.05 & 4.71 & 0.10 & 3.59 & 0.17 & 4.14 & 0.17 \\
\hline Employees & 2.93 & 0.17 & 3.51 & 0.18 & 2.73 & 0.19 & 2.97 & 0.17 \\
\hline Fire Authorities & 3.04 & 0.18 & 2.70 & 0.17 & 2.21 & 0.20 & 2.96 & 0.20 \\
\hline Further Education & 2.41 & 0.29 & 2.18 & 0.29 & 1.89 & 0.20 & 2.61 & 0.30 \\
\hline Health Authorities & 3.00 & 0.13 & 2.75 & 0.14 & 2.20 & 0.15 & 2.88 & 0.15 \\
\hline Local Business & 2.98 & 0.13 & 2.64 & 0.12 & 2.00 & 0.12 & 3.22 & 0.16 \\
\hline Local Media & 2.08 & 0.17 & 2.38 & 0.17 & 2.19 & 0.19 & 2.34 & 0.17 \\
\hline Lower Tie Authorities & 2.59 & 0.30 & 2.65 & 0.32 & 2.28 & 0.23 & 2.94 & 0.38 \\
\hline Management Team & 4.50 & 0.15 & 4.50 & 0.15 & 3.68 & 0.23 & 3.33 & 0.34 \\
\hline Other Local Authorities & 1.93 & 0.20 & 2.07 & 0.25 & 1.89 & 0.20 & 2.35 & 0.31 \\
\hline Partner Agencies & 3.21 & 0.18 & 2.58 & 0.23 & 2.22 & 0.22 & 2.61 & 0.26 \\
\hline Police Authorities & 3.02 & 0.12 & 2.55 & 0.14 & 2.12 & 0.14 & 2.93 & 0.15 \\
\hline $\begin{array}{l}\text { Political Parties in } \\
\text { General }\end{array}$ & 3.29 & 0.23 & 3.00 & 0.25 & 2.29 & 0.22 & 2.53 & 0.28 \\
\hline Pressure Groups & 2.97 & 0.20 & 2.90 & 0.16 & 2.18 & 0.17 & 3.06 & 0.22 \\
\hline Service Users & 3.21 & 0.17 & 3.79 & 0.19 & 2.59 & 0.22 & 4.08 & 0.18 \\
\hline
\end{tabular}




\begin{tabular}{|l|l|l|l|l|l|l|l|l|}
\hline Trade Unions & 1.85 & 0.19 & 2.15 & 0.25 & 1.29 & 0.13 & 1.67 & 0.23 \\
\hline Upper Tie Authorities & 2.25 & 0.15 & 2.20 & 0.17 & 1.70 & 0.16 & 2.19 & 0.18 \\
\hline Voluntary Sector & 2.71 & 0.17 & 2.37 & 0.15 & 1.83 & 0.12 & 2.97 & 0.17 \\
\hline
\end{tabular}

Source: Data Analysis.

\section{Criterion 2: The Definition of Priorities On Services}

The second criteria aimed to measure how much influence each stakeholder has to influence decisions involving service priorities. Once again, councilors are regarded as the strongest influential $(4.71 ; 0.10)$. The management team is also regarded as a strong influence stakeholder $(4.50 ; 0.15)$ but less influential than councilors.

\section{Criterion 3: The Definition of Performance Criteria}

The third criterion assesses power to influence the criteria through which performance is to be assessed. At this time, the Audit Commission is regarded as the strongest influential stakeholder (4.71; $0.13)$ followed by central government $(4.62 ; 0.10)$. Due to standard error, the averages almost overlap and this fact can be explained by their institutional links.

\section{Criterion 4: The Definition of the Most Important Customers}

The fourth criterion is related to stakeholder power a potential customer to be satisfied. At this time, citizens were regarded as the strongest influential stakeholders $(4.27 ; 0.13)$. Councilors and service users are also regarded as representing strong influence $(4.14 ; 0.17$ and $4.08 ; 0.17$ respectively).

\section{Criterion 5: Power to Control Critical Assets}

The fifth criterion assesses stakeholder power as a result of controlling the assets that the local authority employs to carry on its activities. The table below presents the results for this and for the following criteria. The respondent regarded the management team as the strongest influential stakeholder $(4.65 ; 0.15)$. Councilors and central government are also regarded as representing strong influence ( $4.58 ; 0.15$ and $4.48 ; 0.10$ respectively).

\section{Criterion 6: Power to Control Technical Skills}

The sixth criterion assessed stakeholders' power for controlling technical skills. In this criterion, the respondents regarded councilors as the strongest influential $(4.59 ; 0.15)$. The management team is also regarded as representing strong influence $(4.28 ; 0.24)$. However, the high standard error for the management team's SSI indicates low agreement around this stakeholder's influences in this criterion.

\section{Criterion 7: Power to Influence the Service Delivery Process}

Table 7: Stakeholders' power to influence the service delivery process

\begin{tabular}{|l|l|l|l|l|l|l|}
\hline \multirow{2}{*}{ Stakeholders } & \multicolumn{2}{|l|}{ Criterion 5 } & \multicolumn{2}{l|}{ Criterion 6 } & \multicolumn{2}{l|}{ Criterion 7 } \\
\cline { 2 - 7 } & Mean & SE & Mean & SE & Mean & SE \\
\hline Audit Commission & 2.15 & 0.30 & 2.19 & 0.31 & 3.43 & 0.20 \\
\hline Central Government & 4.48 & 0.11 & 3.75 & 0.16 & 3.61 & 0.16 \\
\hline Citizens & 2.19 & 0.14 & 3.36 & 0.17 & 3.38 & 0.14 \\
\hline Contractors & 2.28 & 0.24 & 2.94 & 0.37 & 3.18 & 0.30 \\
\hline Councilors & 4.58 & 0.15 & 4.59 & 0.16 & 4.22 & 0.14 \\
\hline Employees & 2.95 & 0.21 & 3.17 & 0.19 & 4.13 & 0.17 \\
\hline
\end{tabular}




\begin{tabular}{|l|l|l|l|l|l|l|}
\hline Fire Authorities Education & 2.30 & 0.24 & 2.74 & 0.24 & 2.87 & 0.19 \\
\hline $\begin{array}{l}\text { Further } \\
\text { Organizations }\end{array}$ & 1.94 & 0.25 & 2.53 & 0.27 & 2.00 & 0.23 \\
\hline Health Authorities & 2.13 & 0.16 & 2.83 & 0.16 & 2.80 & 0.15 \\
\hline Local Businesses & 1.98 & 0.13 & 2.82 & 0.15 & 2.58 & 0.12 \\
\hline Local Media & 1.33 & 0.10 & 1.95 & 0.17 & 2.60 & 0.17 \\
\hline Lower tie authorities & 1.72 & 0.23 & 2.59 & 0.30 & 2.35 & 0.31 \\
\hline Management Team & 4.65 & 0.15 & 4.28 & 0.24 & 4.47 & 0.16 \\
\hline Other local authorities & 1.65 & 0.19 & 1.71 & 0.19 & 1.94 & 0.16 \\
\hline Partner Agencies & 2.35 & 0.33 & 2.68 & 0.24 & 2.33 & 0.21 \\
\hline Police Authorities & 2.20 & 0.17 & 2.85 & 0.15 & 2.73 & 0.15 \\
\hline Political Parties in General & 2.40 & 0.29 & 2.62 & 0.27 & 2.80 & 0.27 \\
\hline Pressure Groups & 1.88 & 0.18 & 2.77 & 0.23 & 2.84 & 0.14 \\
\hline Service Users & 2.23 & 0.20 & 2.76 & 0.20 & 3.67 & 0.19 \\
\hline Trade Unions & 1.64 & 0.20 & 2.08 & 0.27 & 2.15 & 0.22 \\
\hline Upper tie authorities & 2.36 & 0.24 & 2.29 & 0.15 & 2.48 & 0.20 \\
\hline Voluntary Sector & 1.76 & 0.16 & 2.71 & 0.16 & 2.60 & 0.14 \\
\hline
\end{tabular}

Source: Data Analysis.

The seventh criterion assessed stakeholders' power for influencing the whole service delivery process. In this criterion, the management team is regarded as the strongest influential stakeholder $(4.47 ; 0.16)$. Councilors and employees are also regarded as representing strong influence $(4.22 ; 0.14$ and $4.13 ; 0.17$ respectively).

\section{Reliability Analysis on Stakeholder Identification}

One limitation of this investigation is placed upon the SNI, whose results ranked stakeholders as more or less present in the decision-making process of English Local Authorities. Some stakeholders achieved a low index and this problem could undermine the reliability of the SSI results. In order to improve the reliability of the findings, a goodness of fit analysis is done through the chi-square test.

Table 8: The Chi-Square Test Calculation

\begin{tabular}{|l|l|l|l|l|}
\hline \multicolumn{2}{|l|}{ Stakeholder List } & $\chi^{2}$ & $P$ & $\begin{array}{l}\text { Minimum } \\
\text { Frequency }\end{array}$ \\
\hline 1 & Audit Commission & 3.40 & 0.334 & 4 \\
\hline 2 & Central Government & 8.35 & 0.039 & 14 \\
\hline 3 & Citizens & 15.07 & 0.005 & 11 \\
\hline 4 & Contractors & 9.77 & 0.045 & 3 \\
\hline 5 & Councilors & 20.63 & 0.000 & 19 \\
\hline 6 & Employees & 21.81 & 0.000 & 8 \\
\hline 7 & Fire Authorities Educational & 15.00 & 0.004 & 4 \\
\hline 8 & Further & & 0.172 & 4 \\
& Organizations & 12.39 & 0.006 & 10 \\
\hline 9 & Health Authorities & 25.39 & 0.000 & 10 \\
\hline 10 & Local Businesses & 12.71 & 0.013 & 6 \\
\hline 11 & Local Media & 2.71 & 0.608 & 3 \\
\hline 12 & Lower Tie Authorities & 6.12 & 0.047 & 6 \\
\hline 13 & Management Team & 1.08 & 0.584 & 4 \\
\hline 14 & Other Local Authorities & 1.00 & 0.607 & 6 \\
\hline 15 & Partner Agencies & 14.60 & 0.002 & 10 \\
\hline 16 & Police Authority & 1.20 & 0.753 & 5 \\
\hline 17 & Political Parties & & \\
\hline
\end{tabular}




\begin{tabular}{|l|l|l|l|l|}
\hline 18 & Pressure Groups & 9.67 & 0.046 & 6 \\
\hline 19 & Services Users & 13.43 & 0.009 & 6 \\
\hline 20 & Trade Unions & 2.00 & 0.368 & 4 \\
\hline 21 & Upper Tie Authorities & 14.00 & 0.003 & 7 \\
\hline 22 & Voluntary Sector & 5.29 & 0.151 & 9 \\
\hline
\end{tabular}

Source: Data Analysis.

In this matter, Keppel and Zedeck (1989) defined reliability as "the consistency with which the variable of interest can be assessed". Sapsford and Jupp (1996) argued that the chi-square test could be used to assess goodness of fit in variables of nonparametric distributions, which is the case of this investigation. Coakes and Steed (1999) suggest that, in order to be acceptable, the results of the chisquare test must comply with the following parameters:

. The chi-square result must be higher than 5;

. Confidence level must be $95 \%$ at least;

. The variable should be represented in, at least, 5 units of the sample.

Table 9 presents the results for the chi-square calculation. The highlighted stakeholders are those that do not comply with the rules outlined above. This fact means that these stakeholders should have their SSIs disregarded from the investigation and further analysis should be done with them. Therefore, this investigation has no evidence to consider their salience for decision-making.

\section{DISCUSSION}

The results of this investigation indicate that English Local Authorities are stakeholder-based organizations with some stakeholder influences being critical to the process. As a key issue in the New Labour agenda since 1997 (DRIVER; MARTELL, 1998), the investigation found empirical evidence to support the assumption that English Local Authorities have to take stakeholders' opinions and expectations into account when devising their strategies.

First and foremost, the stakeholder concept has to be dealt with. According to Freeman (1984), a stakeholder is any person, group or organization able to influence the organization or to be influenced by the organization's objectives and operations. According to this broad definition, the people, groups and organizations included in this investigation are very likely to be accepted as stakeholders. However, if we look at more specific definitions of stakeholders, such as that proposed by Mitchell et al. (1997), which expanded Freeman's concept scope by introducing a third dimension, further considerations need to be made.

According to the criteria of power proposed in this article, a stakeholder is able to influence an organization when possessing control over resources, control over a technical skill, and control over a body of knowledge, power stemming from legal prerogatives, and access to those who can rely on the previous sources of power. Below, some stakeholders have their relationship with local governments analyzed.

- Central government has power because it controls resources, which indicates a dependence relationship between it and local governments. Central government also has legitimacy because its activities are legally supported by acts of Parliament. According to Mitchell et al.'s model, central government can be regarded at least as a dominant stakeholder.

. Councilors have power because they are empowered by legal prerogatives to do so. They also have legitimacy due to legal prerogatives. For this reason, councilors can also be regarded as dominant stakeholders; 
The management team has power because it has control over a technical skill. The relationship between the management team officers and the elected members can be seen in the light of agency theory. In some cases, senior officers (agents) are empowered to make decisions on behalf of the councilors (principal);

Public partners (health, police, fire authorities, and other local authorities) have legitimacy for influencing decision-making in the scope of their attributions as public service deliverers. Their power and urgency do not seem to be a general issue in the local government affairs and they are to be dealt with case-by-case. For this reason, these stakeholders are labeled as discretionary;

- Citizens, local businesses and service users do not have power. There have to pay taxes and this could lead to a dependence relationship. However, local authorities in England do not rely heavily upon incomes from local taxpayers because around $70 \%$ of their budgets are funded by transferences from central government. On the other hand, it is indisputable that these stakeholders have legitimacy as well as urgency in their demands to which local government has a duty to meet.

In terms of stakeholder's salience, the investigation sheds light on local government stakeholder management theory by pinpointing the powerful stakeholders according to the seven criteria presented above. Starting from this point, scholars can investigate in detail these stakeholders' modus operandi in order to consider better ways for dealing with them.

The evidence presented in this report is supported by the chi-square calculation. In such an analysis, some of the SSIs are not corroborated due to nonconformity with the chi-square parameters and this is in part due to their low SNI. However, the problem does not disqualify the findings. Rather, it indicates that further analysis should be done in this barely explored field. It would be helpful to investigate how different types of local public services perceive stakeholders' salience. It would be also helpful to compare public and private service delivering processes in order to figure out to what extent they agree about a stakeholder's identification and salience. For the moment, the list proposed in this investigation would be a helpful starting point for further research.

Comparing the overall findings on stakeholder's identification and salience and the chi-square results, a stakeholder's map is proposed. In the map, the decision-making process of English Local Authorities is placed at the centre, being surrounded by several orbits of stakeholders. Each orbit represents a class of stakeholders to whom decision-makers have to dedicate different amount of attention. Due to the chi-square results, some of the listed stakeholders (see Table 5) are not included in the map. The investigation suggests that they are important stakeholders and liable to be included in further studies. In terms of stakeholder management, the investigation pinpoints the strong influential stakeholders whose action should be thoroughly monitored and who are scattered throughout the map. Figure 3 presents the map. 
Figure 3: A Generic Stakeholder's Map for English Local Authorities

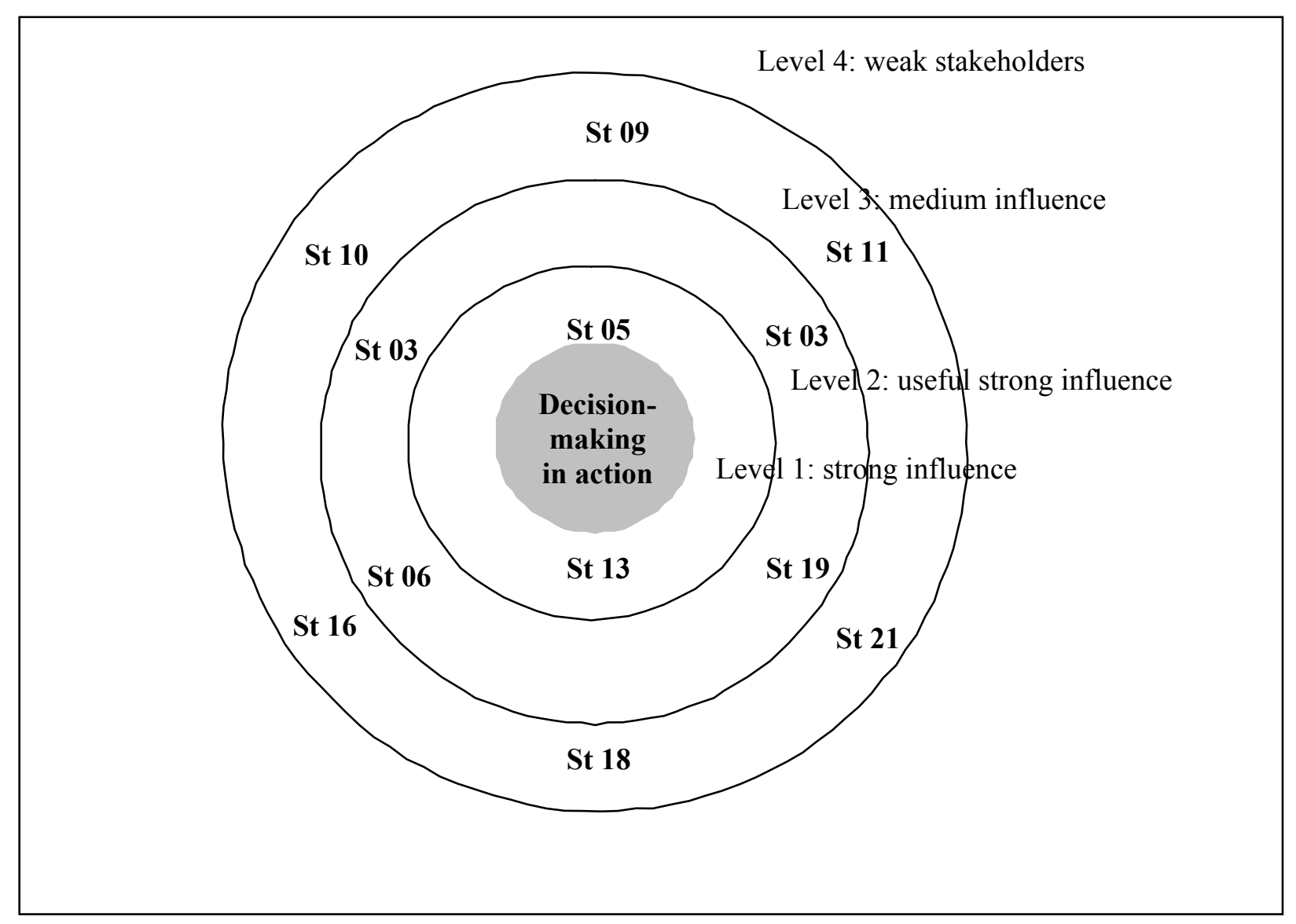

\section{CONCLUSION}

This paper presents an investigation carried out with the chief executives of English Local Authorities. Its main aim has been to identify who the people, groups and organizations regarded by the authorities as a stakeholder are. To this end, the investigation gathered evidence concerning stakeholder identification and salience based on criteria of power and interest.

The investigation raises two types of contributions to the current literature. An empirical contribution is issued by identifying the stakeholder who is able to influence decision-making and therefore able to raise issues in the strategic management of such organizations. The other empirical contribution is the depiction of a stakeholder's map in which stakeholders are rated according to their ability to influence decision-making. The stakeholder's map would help decision-makers in English Local Authorities to identify those stakeholders who are likely to represent a threat or an opportunity.

A theoretical contribution of the findings is related to the normative basis of the stakeholder theory. Evidence gathered in this investigation corroborates Donaldson and Preston's (1995) arguments about the normative basis of the stakeholder theory to the extent that it suggests diversity in stakeholder management. From the findings, it can be learned that the relationships with stakeholders are to be managed employing different strategies because all of them assume different roles in decision-making and have different degrees of importance for the process. 
As an indication for further investigations, the findings raise the importance of identifying how stakeholder influences come about in local government decision-making. It would be worthwhile to know what part of decision-making influences is exerted as well as the modus operandi of stakeholder influences. This information would shed light on the patterns of relationships between stakeholders and local government's organizations, e.g., in the accountability process.

Another issue is related to the stakeholder identification framework. This investigation has proved that stakeholder identification is neither based on political, nor geographical contexts. Chief executives have nominated stakeholders in an almost homogeneous manner. However, a stakeholder's identification might be a service-based issue, and depending on the nature of the service to be delivered different types of stakeholders (perhaps with different amount of power) would arise. Therefore, comparisons between different types of services within the very same authority are welcomed to the field.

Looking at replication, this investigation can be seen as a starting point to introduce the stakeholder concept to other realities despite the nature of the field investigated. The investigation was carried out in a parliamentary and monarchical country. This fact means that the findings need to be looked at carefully to avoid misinterpreting their main contributions to the literature. In Brazil, counties are very likely to adopt stakeholder management because public functions carried here are similar to those carried by local governments in England as demonstrated before. Overall, local decision makers in Brazil are very likely to deal with the same sort of stakeholders as in England.

This investigation concludes that the decision-making of local government organizations have relationships with a myriad of stakeholders, each one able to influence it. In such a process, decisionmakers have to acknowledge environmental influences as sources of opportunities to be exploited as well as threats to be avoided. From this point, local government stakeholder management theorists should dedicate their attention to studying in-depth the relationships between local government and the sources of influence raised in this article.

\section{ACKNOWLEDGEMENTS}

My sincere gratitude to CAPES - Ministério da Educação - Brazil without whose support anything would have happened.

\section{NOTES}

${ }^{1}$ A professional who was hired to manage the administrative machine of local administrations.

\section{REFERENCES}

COUNTRYSIDE A. 2002. The State of the Countryside 2001. Wetherby: Countryside Agency. Available from. Disponível em: $<$ http://www.countryside.gov.uk $>$.

BLAIR, J. D.; BUESSELER, J. A. Competitive Forces in the Medical Group Industry: A Stakeholder Perspective. Health Care Management Review, v. 23, n. 2, p. 7-27. 1998.

BRYMAN, A. Social Research Methods. Oxford: Oxford University Press. 2001

BRYSON, J. Strategic Planning For Public and Non-Profit Organization. San Francisco: JosseyBass Publishers. 1995 
COAKES, S. J.; STEED, L. G.SPSS: Analysis without Anguish. Brisbane: John Wiley \& Sons. 1999

DIMAGGIO, P. J.; POWELL, W. W. The iron cage revisited: institutional isomorphism and collective rationality in organizational fields. In: W. W. POWELL; DIMAGGIO P. J. (Ed.). The New Institutionalism in Organizational Analysis. Chicago: The University of Chicago Press, 1991.

DONALDSON, T.; PRESTON, L. E. The Stakeholder Theory of the Corporation: concepts, evidences, and implications. Academy of Management Review, v. 20, n. 1, p. 65-91. 1995.

DRIVER, S.; MARTELL, L. New Labour, politics after Thatcherism. Cambridge: Polity Press. 1998

ENZ, C. A. et al. Graduate-Level Education: A Survey of Stakeholders. The Cornell H.R.A Quarterly, August, p. 90-95. 1993.

FOTTLER, M. et al. Assessing Key Stakeholders: Who Matters to Hospitals and Why? Hospital \& Health Services Administration, v. 34, n. 4, p. 525-546. 1989.

FREEMAN, R. E. Strategic Management: A Stakeholder Approach. Massachusetts: Pitman. 1984

GREENING, D. W.; GRAY. B. Testing a Model of Organizational Response to Social and Political Issues. Academy of Management Journal, v. 37, n. 3, p. 467-498. 1994.

HANNAN, M. T.; FREEMAN. J. The Population Ecology of Organizations. American Journal of Sociology, v. 82, n. 5, p. 929-964. 1977.

HARDY, C. Understanding Power: Bringing about Strategic Change. British Journal of Management, v. 7, n.Special Issue, March, p. S3-S16. 1996.

KATZ, D.; KAHN, R. L. The Social Psychology of Organizations: John Wiley \& Sons, Inc. 1978

KEPPEL, G.; ZEDECK, S. Data analysis for research designs, analysis of variance and multiple regression/coorelation approaches. New York: W. H. Freeman. 1989 (A Series of books in psychology)

KUMAR, K.; SUBRAMANIAN. R. Meeting the Expectations of Key Stakeholders: Stakeholder Management in the Health Care Industry. SAM Advanced Management Journal, Spring, p. 31-40. 1998.

MEYER, J. W.; ROWAN, B. Institutionalized Organizations: formal structure, myth, and ceremony. In: POWELL, W. S.; DIMAGGIO, P. J. (Ed.). The New Institutionalism in Organizational Analysis. Chicago: The University of Chicago Press, 1991. Institutionalized Organizations: formal structure, myth, and ceremony

MILlER, D. C.; SALKIND, N. J. Handbook of Research Design \& Social Measurement. Thousand Oaks: Sage Publications. 2002

MILLER, S.; WILSON, J. Perceptions of Stakeholding: The Case of an NHS Trust. Public Money \& Management, .Jul-Sep, p. 51-58. 1998.

MINTZBERG, H. Power in and around Organizations. New Jersey: Prentice Hall, Inc. 1983

MITCHELL, R. K. et al. Toward a theory of stakeholder identification and salience: defining the principle of the who and what really counts. Academy of Management Review, v. 22, n. 4, Oct, p. 853-886. 1997. 
MWANKWO, S.; RICHARDSON, B. Organizational leaders as political strategists: a stakeholder management perspective. Management Decision, v. 34, n. 10, p. 43-49. 1996.

OLIVER, C. Strategic Responses to Institutional Processes. Academy of Management Review, v. 16, n. 1, Jan, p. 145-179. 1991.

ORRÙ, M. et al. Organizational Isomorphism in East Asia. In: POWELL, W. S.; DIMAGGIO, P. J. (Ed.). The New Institutionalism in Organizational Analysis. Chicago: The University of Chicago Press, 1991. Organizational Isomorphism in East Asia, p. 361-389

PFEFFER, J.; SALANCIK, G. R. The External Control of Organizations: A Resource Dependence Perspective. New York: Harper and How. 1978

RAHMAN, S. A. Comparative Study of TQM practice and organisation performance of SMEs with and without ISO 9000 certification. International Journal of Quality and Reliability Management, v. 18, n. 1, p. 35-49. 2001.

SAPSFORD, R.; JUPP, V. Data Collection and Analysis. London: Sage Publication. 1996

SAVAGE, G. T. et al. Strategies for Assessing and Managing Organizational Stakeholders. Academy of Management Executive, v. 5, n. 2. 1991.

SELZNICK, P. TVA and the Grass Roots: a study in the Sociology of Formal Organization. New York: Harper Torchbooks. 1966

STONEY, C.; WINSTANLEY, D. Stakeholding: Confusion or Utopia? Mapping the Conceptual Terrain. Journal of Management Studies, v. 38, n. 5, July, p. 603-626. 2001.

WINSTANLEY, D. et al. When the Pieces Don't Fit: A Stakeholder Power Matrix to Analyse Public Sector Restructuring. Public Money \& Management, Apr/Jun, p. 19-26. 1995. 